\title{
Original
}

\section{Contrast Adjusted}

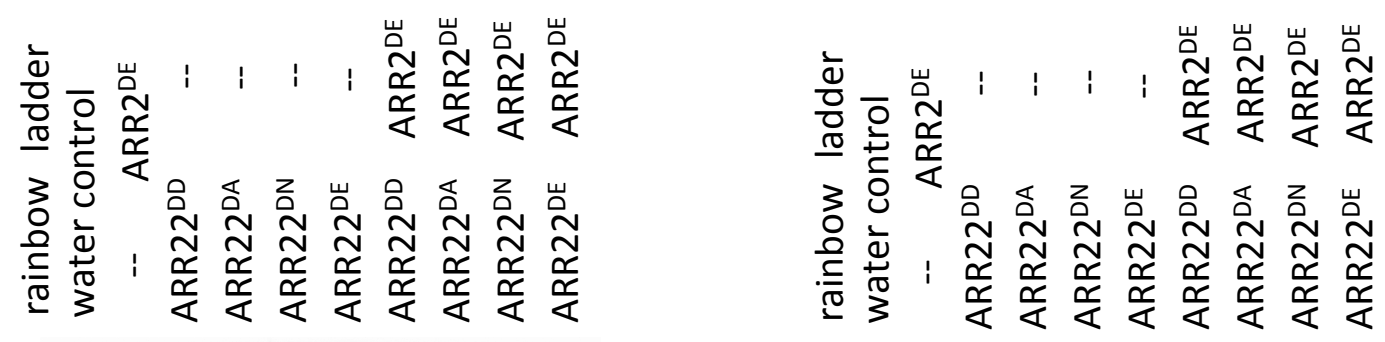

$3 \times H A-A R R 2^{D E}$

$3 \times$ HA-ARR22 ${ }^{X X}$

Specific Detection with $\alpha-H A-r a t / \alpha-r a t-H R P / E C L$ detection

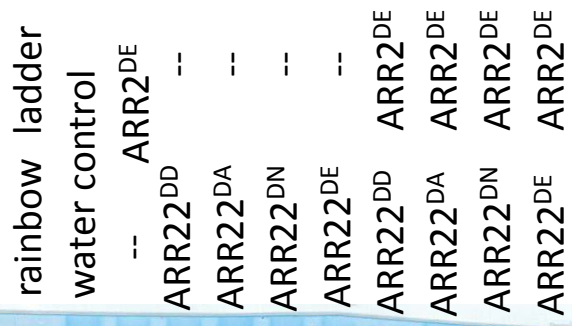

Fig S7 